\begin{abstract}
S
The Editors are grateful to Eleni Andrikou, Lena Papazoglou-Manioudaki, and especially Helen Cavanagh for assistance in the preparation of the Greek abstracts.

\section{J. BOUZEK}

Late bronze age Greece and the Balkans: a review of the present picture

This article brings a reassessment of the survey of relations published in the author's 1985 book. The discrepancy in chronology seems now to be much nearer to a solution: more material evidence is known from the frontier area and from the Balkans in general, thus enlarging the documentation of the extent of Mycenaean influence in the north, and also clarifying the situation in Late Mycenaean times, when various northern influences were felt in Mycenaean Greece. The crisis at the end of the Aegean Bronze Age was connected with an influx of new populations, though substantial local traditions were also retained. The joint efforts of tradition and innovation prepared the further development of Greece.
\end{abstract}

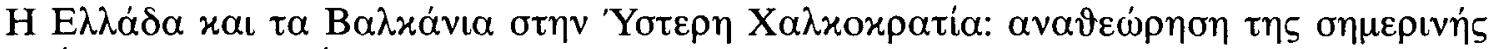

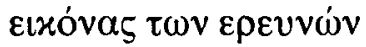

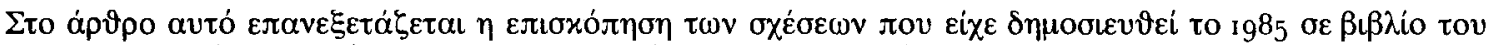

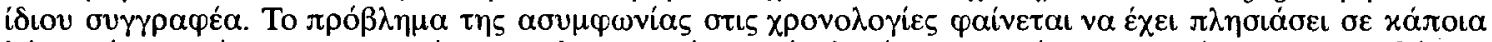

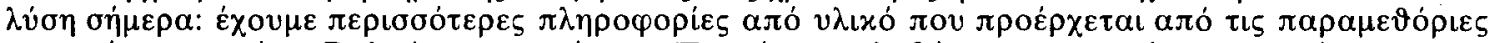

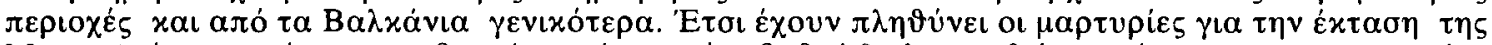

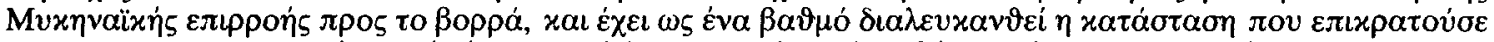

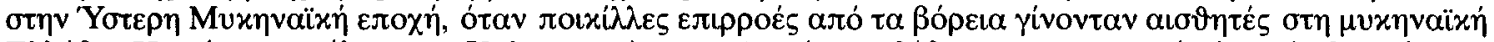

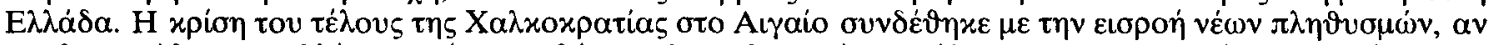

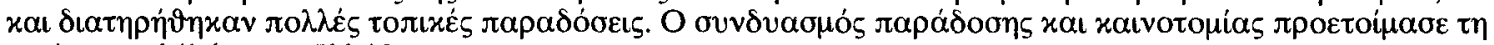

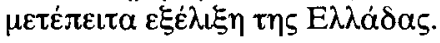

\section{Jill Carington SMith}

$359-76$

A late hellenistic wine press at Knossos (with an appendix by SHEILAGH WALL) (Plates 49-52)

In a rescue excavation at Knossos in 1977 , a building dating to the last years of the hellenistic period was discovered. In it were an area with a stone tub and lid, the use of which was unknown, a well, and a wine press. The wine press had a treading-floor with remains of flooring composed of flagstones and plaster, which sloped towards a hole in a low barrier wall. The hole gave onto a stone spout, set above a tank coated in waterproof plaster. Adjacent was part of a store building, which was probably used as a cellar: it contained one pithos and there were indications that there had been others. Two tests below the building uncovered the violent destruction of a house of earlier hellenistic date, a stratum with sherds of the end of the 8th cent.-beginning of the 7 th cent. BC, and scanty remains of the Minoan period.

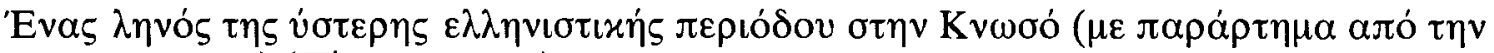 SHEILAGH WALL) (Пivaxe5 49-52)}

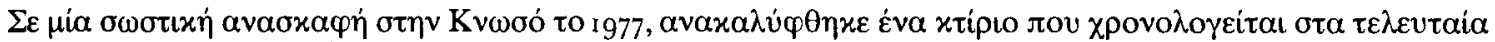

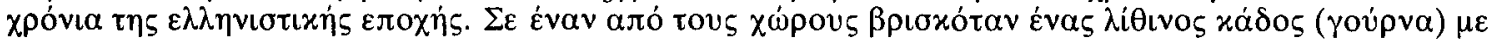




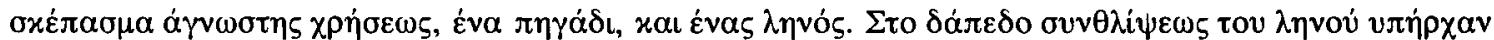

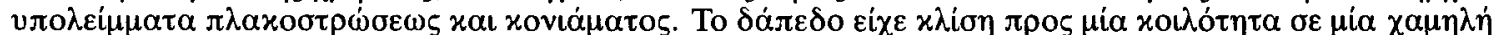

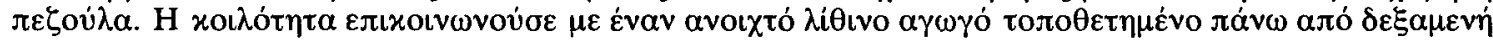

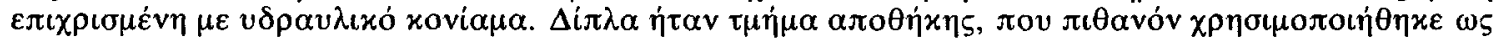

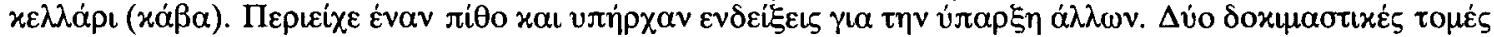

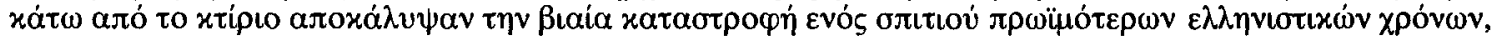

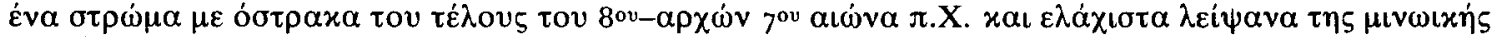
влохทंड.

\section{R. W. V. Catling}

A fragment of an archaic temple model from Artemis Orthia, Sparta

A fragment of an archaic temple model from the British School's early excavations at the sanctuary of Artemis Orthia at Sparta is published. It is suggested here that its decoration represents a timber-framed building. Support for this argument is found in the similar construction technique used for the early 7 th-cent. temple of Artemis Orthia. Its contribution to the debate concerning the evolution of the developed Doric order is considered. In further discussion of the significance of votive 'house models', doubts are expressed about the universal applicability of recent explanations linking them with female cults explicitly associated with protection of the household.

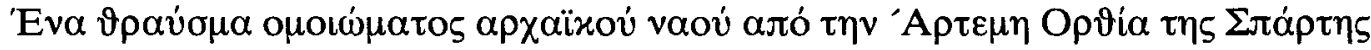

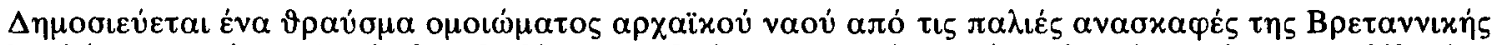

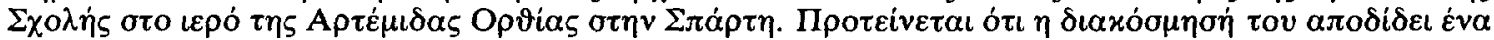

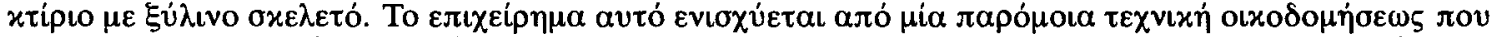

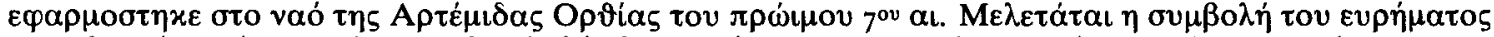

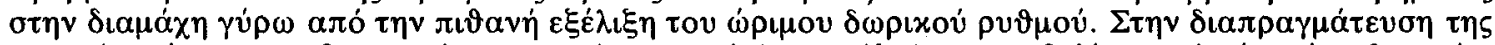

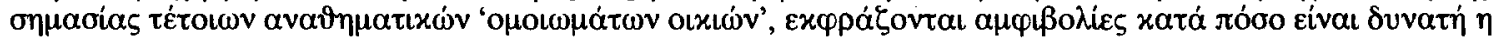

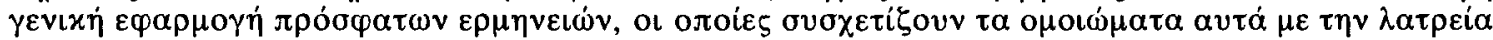

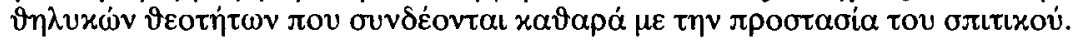

SiRIOL DAVIES

$433-55$

Tithe-collection in the Venetian Peloponnese $1696-1705$

The tithe was the most important source of revenue for the Venetian government in the Morea. The initial practice of farming out the collection of the tax each year to private individuals was later partially replaced by a system reminiscent of Ottoman practice, whereby the village communities became responsible for their own tithe. This policy encouraged the villages to negotiate directly with the provincial authorities, but met with limited success. The article concludes that the system failed in terms of both its primary aim of recovering sufficient revenue for the regional government and the secondary aim of conciliating the Greek population.

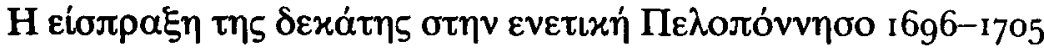

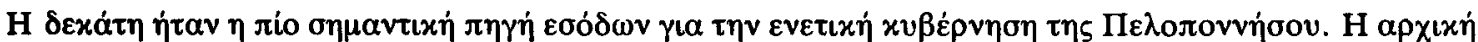

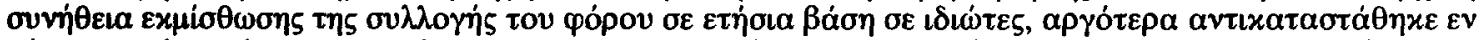

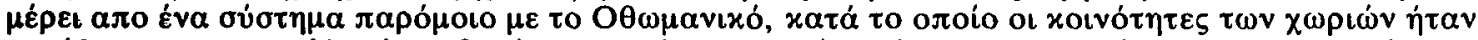

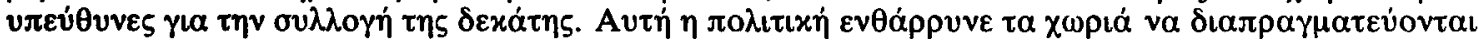




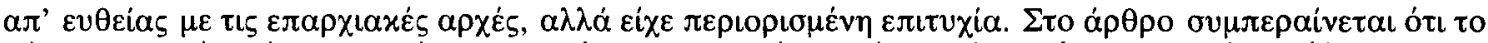

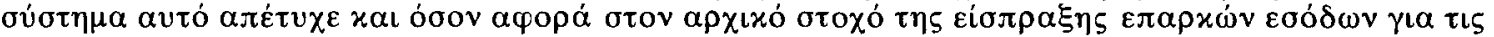

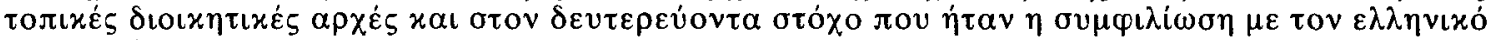
$\pi \lambda \eta \theta v \sigma \mu o ́$.

\section{O. HANSEN}

A Mycenaean sword from Boğazköy-Hattusa found in I99I

This paper deals with a bronze sword found during repair work on a road close to the Hittite capital of Hattusas in central Anatolia. It carries an Akkadian inscription stating that it was taken as booty by the Hittite king Tuthaliyas II during his campaign in the Assuwa country of western Asia Minor, c.1430 BC. The content of the inscription may be evidence of Ahhiyawan-Mycenaean Greek warfare in western Asia Minor in the Late Bronze Age, and/or of a historical background for the Trojan war.

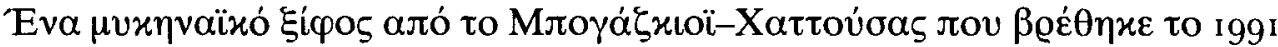

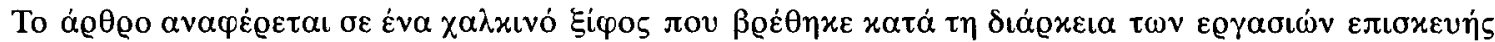

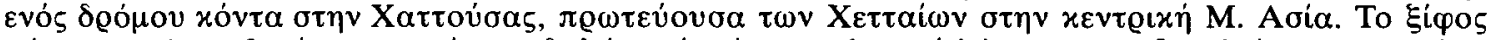

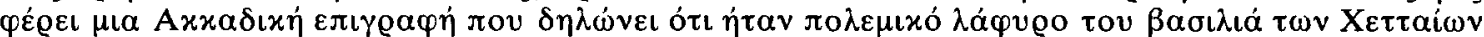

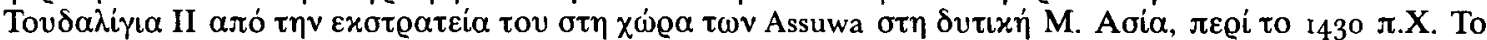

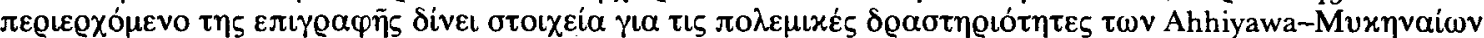

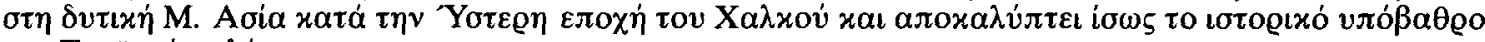

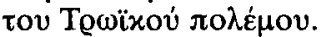

\section{SINCLAIR HOOD}

Knossos: soundings in the Palace area, $1973-87$

Various soundings were made into Minoan Bronze Age deposits in the Palace area in 1969, 1973, and 1987. These include work on the South Front (H.I.6), described here.

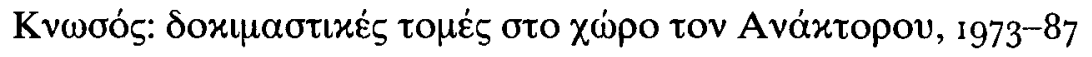

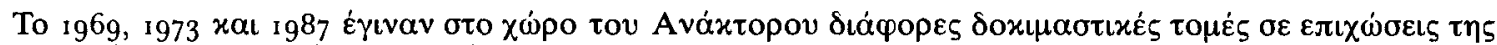

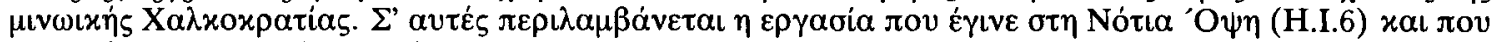

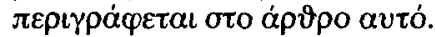

\section{B. S. J. IsSerlin, R. E. Jones, S. Papamarinopoulos, and J. Uren}

The canal of Xerxes on the Mount Athos peninsula: preliminary investigations in 1991-2 (Plates 43-4)

The canal dug by Xerxes across the Mount Athos peninsula in preparation for his invasion of Greece is an important but little-known monument. Geophysical and topographical investigations begun in $199^{1-2}$ now suggest that its central section across high ground ran along a deep trench. Its features elsewhere remain to be determined. 


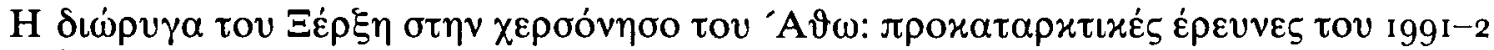 (Пivaxe5 43-4)}

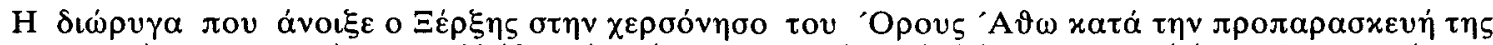

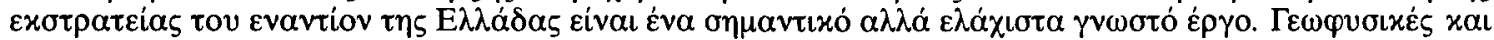

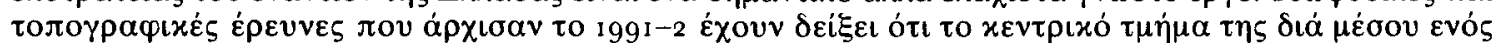

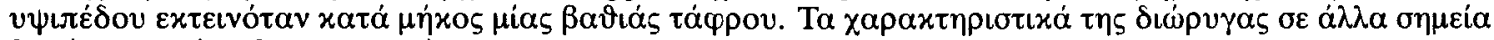

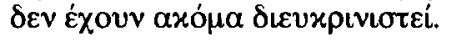

D. M. LEWIS

$285-301$

The Athenian tribute-quota lists, $453-45^{\circ} \mathrm{BC}$

The Athenian tribute-quota lists for the years $453-449 \mathrm{BC}$ are reexamined in the light of two new fragments. The most important question is the reason for the failure of various states to appear in them. The author rejects the view that these absences are due to epigraphic chance, doubts whether many of the states were still providing ships, and argues again that there was substantial disaffection in the empire during the period.

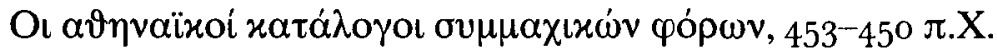

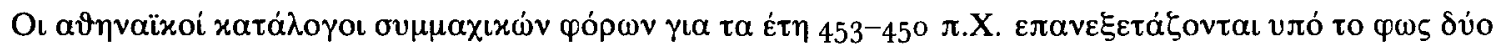

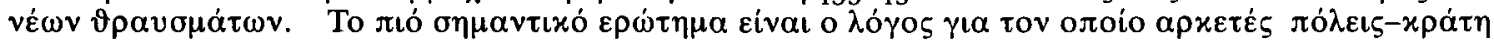

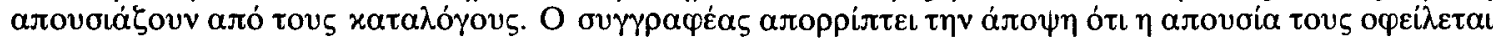

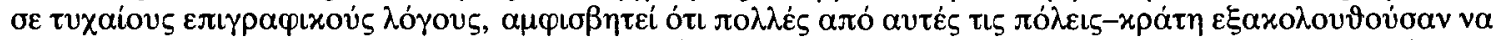

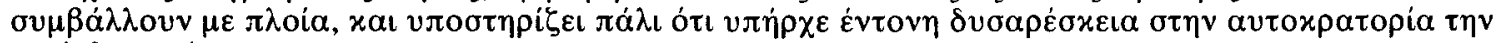
$\pi \varepsilon p i o \delta o \alpha v t \dot{r}$.

Nicoletta Momigliano and Sinclair HoOd $103-50$

Excavations of 1987 on the south front of the palace at Knossos (Plates $15^{-19}$ )

This report describes the excavation of two pits which had been dug into the natural rock, apparently in connection with the storage and perhaps original manufacture of plaster, in the space named after them the 'Room of the Plaster Pits'. The pits were filled and covered in LM II, and the evidence for their date helps to bring the history of this part of the palace into clearer focus. The Room of the Plaster Pits may be the same as the elusive Lapidary's Workshop described by Evans in his Knossos report for 19o1. It is suggested that the lack of observed floors or blocking walls in doorways separating deposits in this area makes it difficult to divide the vases assigned to LM III в here from tablets and seal impressions involved in the final destruction of the palace.

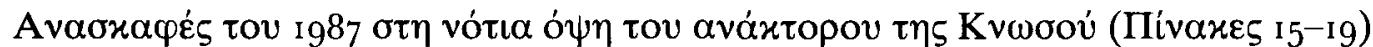

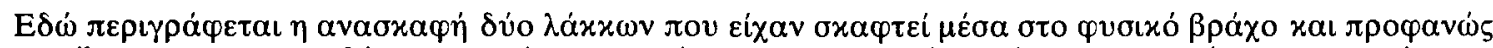

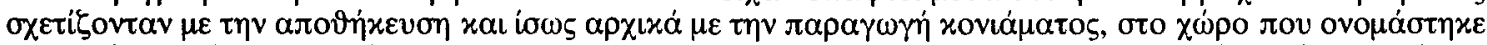

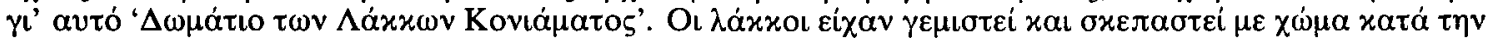

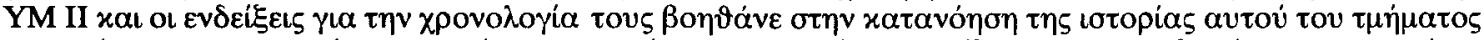

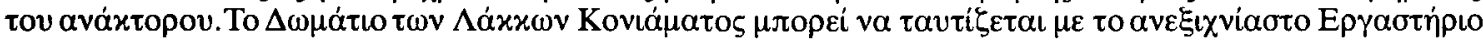

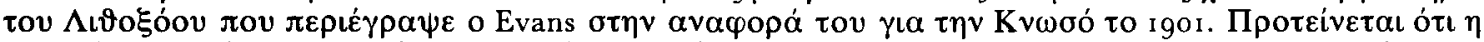

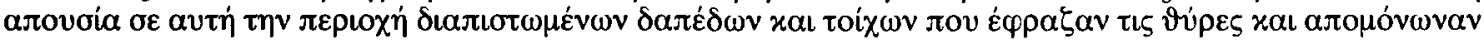

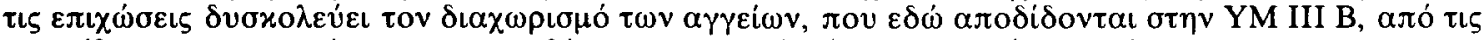

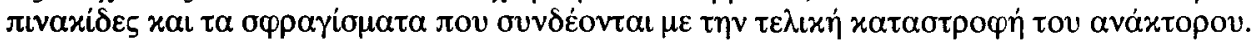


J. H. Musgrave, R. A. H. Neave, A. J. N. W. Prag, E. Sakellarakis, and J. A. SAKELLARAKIS

$89-100$

The priest and priestess from Archanes-Anemospilia: reconstructing Minoan faces (Plate I4)

In 1987 the Manchester team made casts of the skulls of the priest and priestess discovered at Anemospilia (Archanes) by J. A. and E. Sakellarakis, and after careful medical study - which showed that the priestess suffered from anaemia as well as halitosis - reconstructed their faces, according to the technique used on the skull from tomb II at Vergina (Philip II).

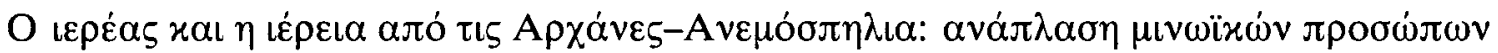 (Пivaxas 14)}

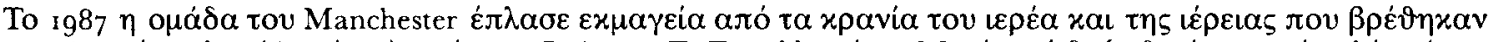

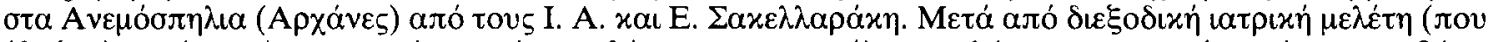

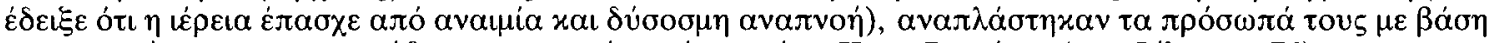

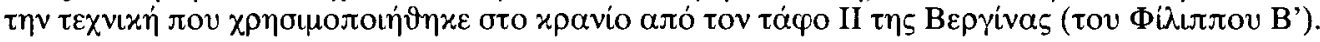

KRZYSZTOF NOWICKI

$235^{-68}$

A dark age refuge centre near Pefki, East Crete (Plates 39-42)

This paper presents the result of the field investigations undertaken at newly identified dark age sites near Pefki, E. Crete, in I990-I. A series of LM III-PG/G settlements (complemented with graveyards) show the same topographical characteristics as ruled the settlement pattern of dark age Crete, and support the idea that it was a serious threat from outside that forced people to abandon the coastal plains and low valleys and look for safety in the mountains. Detailed description of the topographical situation and finds as recorded on the surface are presented, to give comparanda for very restricted evidence published from other dark age sites in Crete.

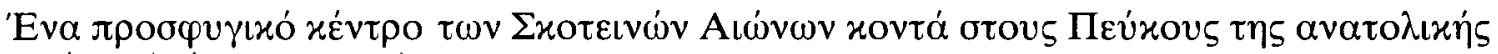

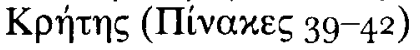

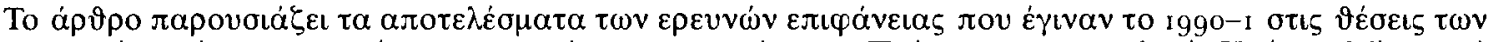

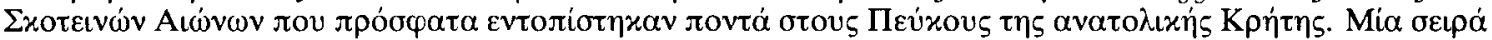

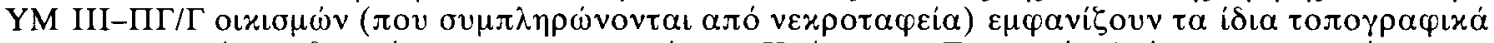

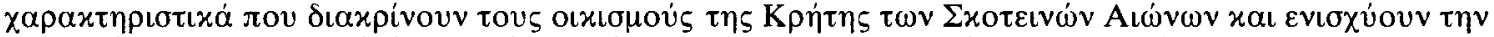

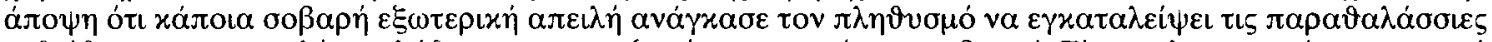

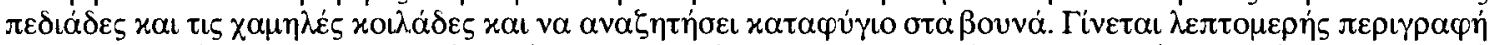

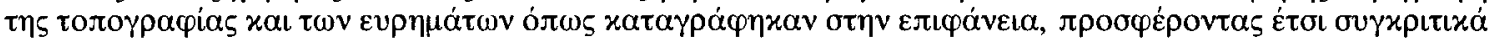

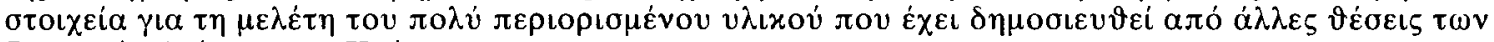

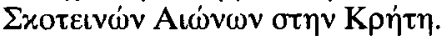

\section{LENA PAPAZOGLOU-MaNiOUdaki}

I7 $1-200$

\section{A Mycenaean warrior's tomb at Krini near Patras (Plates 23-36)}

In 198 $\mathrm{I}$ an unplundered Mycenaean chamber tomb was excavated at Krini Nw of Patras. Two separate layers of burials were found in the chamber, and its use is dated from LH III A to the middle of LH III C. The LH III C warrior's burial is of particular interest. It was furnished with a bronze Naue II sword, which has preserved in good condition its scabbard, made of wood and leather and decorated with bronze strips and studs. The warrior's burial 
and its furnishings are studied here in relation to the other LH III $\mathrm{C}$ warrior burials known from the Patras region, and their significance is discussed. The analysis of the pottery found in the tomb gives evidence for the existence and dating of local pottery workshops active in the region.

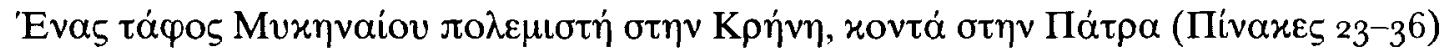

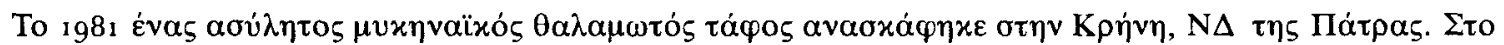

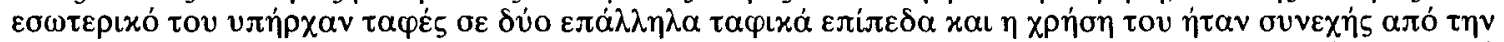

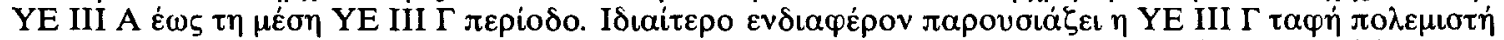

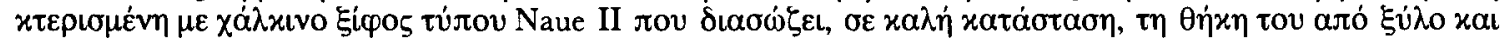

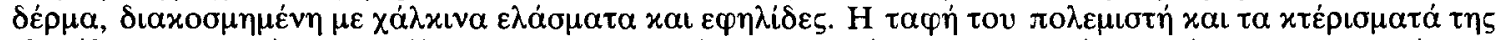

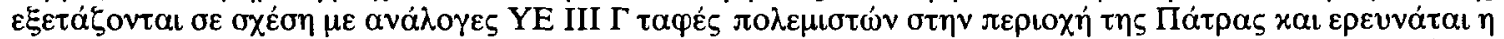

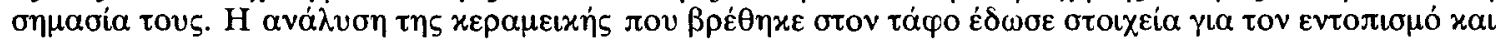

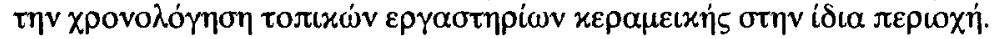

\section{E. Photos-Jones and J. Ellis Jones}

$307-5^{8}$

The building and industrial remains at Agrileza, Laurion (fourth century $\mathrm{BC}$ ) and their contribution to the workings at the site (Plates $45^{-8}$ )

A detailed programme of sample collection and laboratory analysis was undertaken at Agrileza, an ore-dressing installation in the Laurion. The site consists of three compounds with associated washeries (Agrileza A, B, and C), some excavated partially, others in full, in the late I970s and early 1980 os and dating to the last quarter of the $4^{\text {th }}$ cent. BC. The particular functions of some of the rooms in compound $\mathrm{C}$ are tentatively put forward. The main part of the paper is concerned with the nature, composition, and particle size distribution of the tailings recovered both from washeries $\mathrm{A}$ and $\mathrm{C}$ and from elsewhere in compound $\mathrm{C}$. The silver-to-lead ratios and particle size distribution of the tailings may suggest that the series of basins and channels making up each washery served not merely as a water purification device, but as a means of trapping ore that had escaped the first washing, for the purpose of dressing it further.

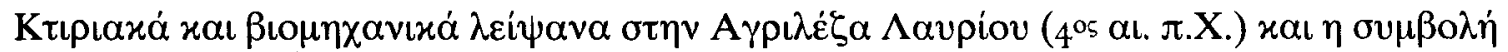

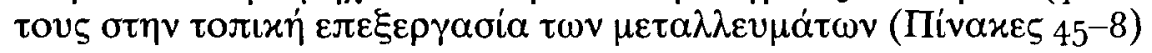

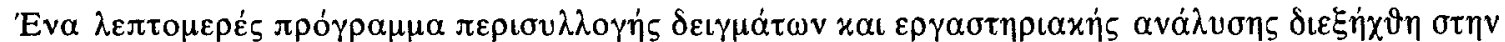

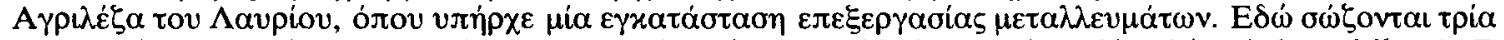

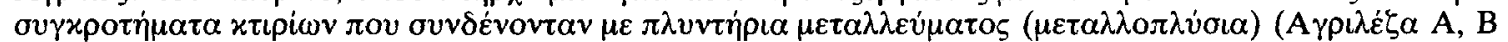

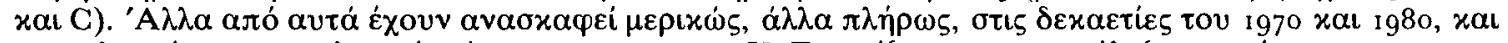

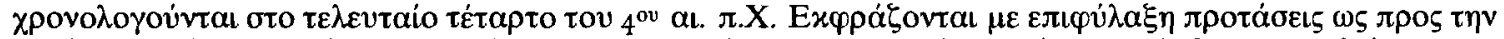

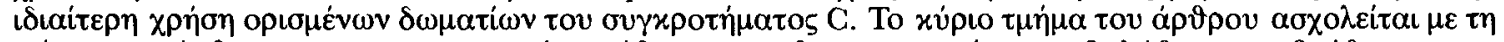

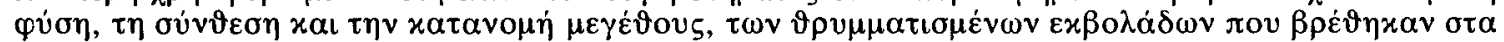

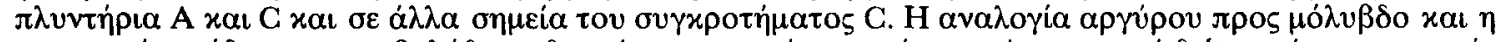

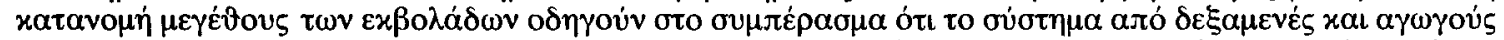

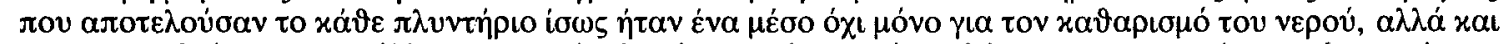

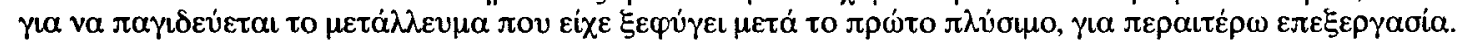

L. SCHOFIELD and R. B. PARKINSON

$157-70$

Of helmets and heretics: a possible Egyptian representation of Mycenaean warriors on a papyrus from el-Amarna (Frontispiece, Plates 2I-2)

This paper examines the representation of soldiers on a painted papyrus from el-Amarna, recently acquired by the British Museum (EA 74100). Features include helmets and short-cropped oxhide tunics; these can be paralleled in 
representations from the Aegean, suggesting that the painting may show figures wearing boar's tusk helmets and Mycenaean-style tunics. This interpretation of the battle scene argues that the Egyptian iconographic repertoire included depictions of Mycenean features. This adds to the evidence for direct, rather than indirect, contacts between the two cultures.

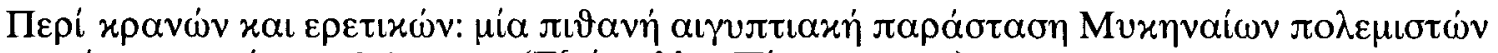

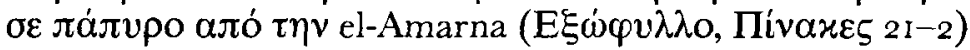

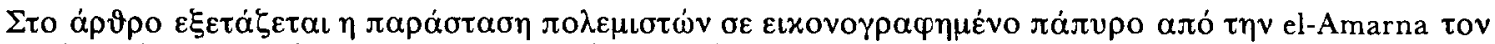

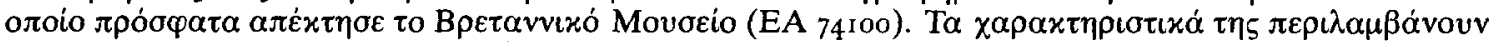

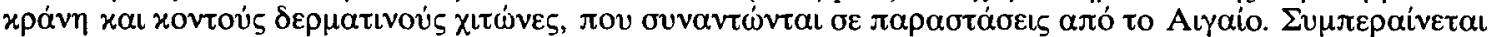

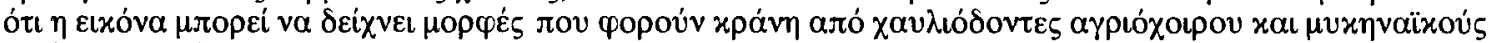

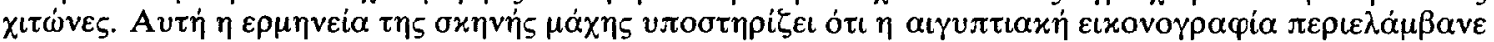

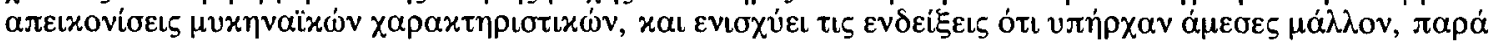

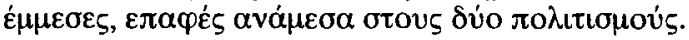

\section{N. V. SEKUNDA}

\section{Iphicrates the Athenian and the Menestheid family of Miletus}

The epigraphic record of Miletus records an eminent family using the names Iphicrates, Menestheus, and Zopyros. The name Iphicrates is not common: it is suggested that it passed into the family after a member of it served under the Athenian general Iphicrates, whose second son was called Menestheus. Apollonios son of Menestheus, strategos of Koile Syria and Phoenicia under Seleucus IV, is probably a descendant of this Milesian family.

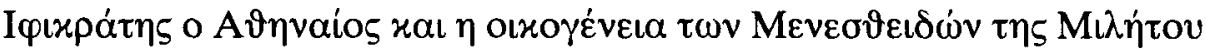

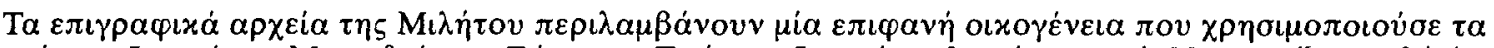
ovó $\mu \alpha \tau \alpha$ I

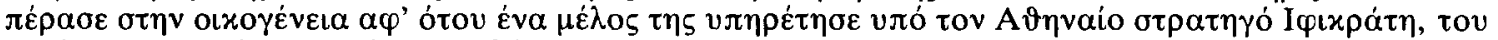

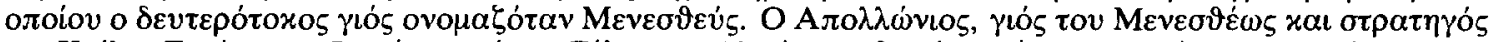

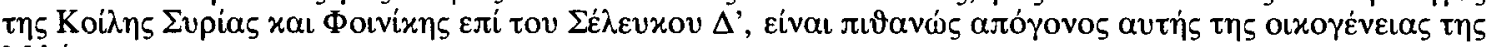
Mìnंนov.

\section{A. J. S. SPAWFORTH}

Excavations at Sparta: the Roman stoa, 1988-91. The inscriptions (Plates 73-8)

Nineteen Greek inscriptions from the recent excavations at the Roman stoa and Roman theatre at Sparta are published. They include two honorific inscriptions of imperial date, one for a previously unknown Octavia Agis, 'descendant of the founder gods of the city Heracles and Lycurgus', and at least four fragments from Romanperiod lists of civic magistrates. Two of these were found in situ and reveal that the proedria of the theatre, as well as the orchestra drain and east parodos, were inscribed with documents of this type.

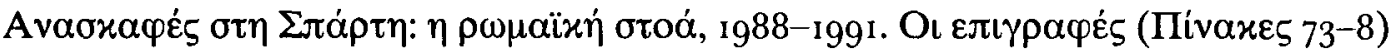

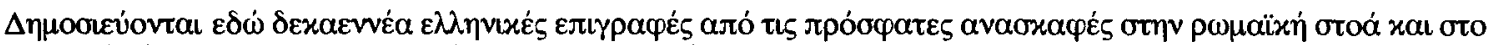

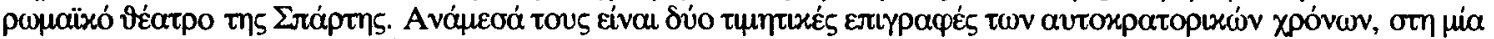

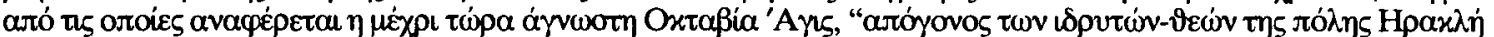

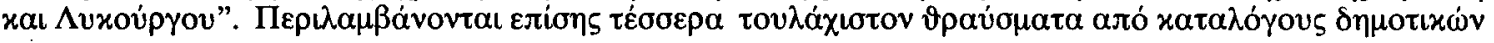




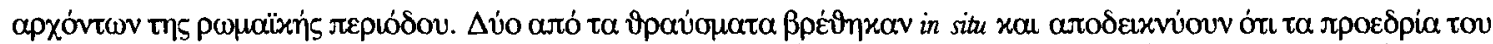

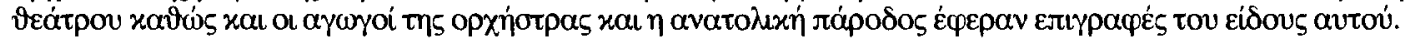

\section{LOUISE STEEL}

Representations of a shrine on a Mycenaean chariot krater from Kalavasos-Ayios Dhimitrios, Cyprus (Plates 37-8)

An important tomb group was discovered during the $199^{2}$ excavations of the Late Cypriot II town at Kalavasos-Ayios Dhimitrios. The tomb contained large quantities of Mycenaean ceramics, ranging in date between LH III A 2 and III B. Of particular importance was a chariot krater with the representation on both sides of a shrine, surmounted by horns of consecration, housing a seated female figure. As yet the iconography is unmatched among the known corpus of Mycenaean pictorial vases, though it appears to be related to Minoan-Mycenaean iconography known from other media.

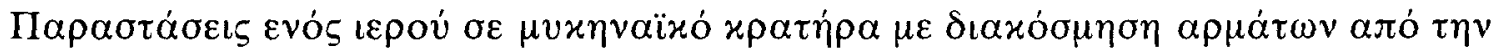

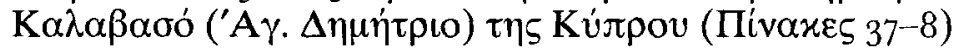

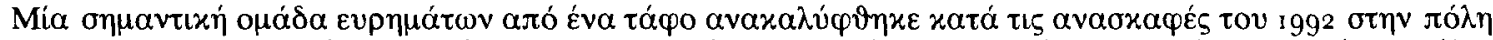

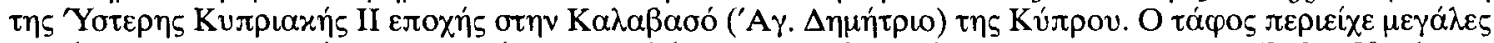

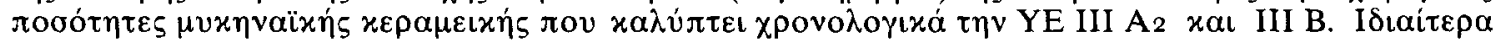

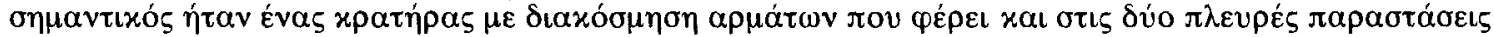

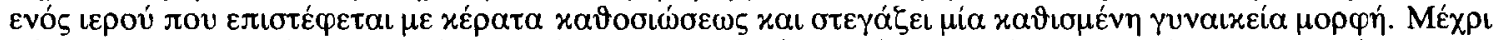

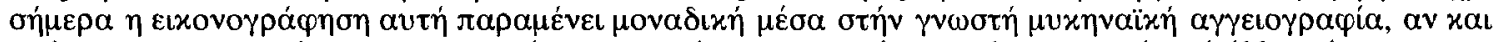

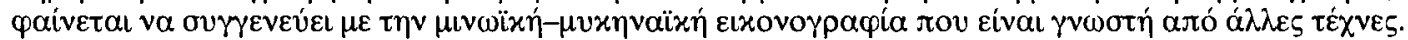

\section{G. B. WAYWELL and J. J. WILKES}

Excavations at Sparta: the Roman stoa, 1988-91. Part 2 (with a contribution by N. FradgLEY) (Plates 53-72)

Survey and excavation between 1988 and 1991 have revealed new evidence for the form, date, and history of the Roman stoa at Sparta. Nearly $200 \mathrm{~m}$ long, it was double-fronted and colonnaded, finished in marble, with two storeys on the $S$ side and perhaps a single portico to the $\mathrm{N}$, set either side of a central row of brick-faced concrete compartments that helped consolidate the acropolis plateau. Its order may have been archaizing Doric; it may have represented a reconstructed version of the Persian stoa. At the $w$ end it buttressed the Round Building and its square podium. Evidence of the stratigraphy and architecture suggests it was built $c$. AD I30 and that the colonnades collapsed in the late $4^{\text {th }}$ cent., after which it was partly incorporated into the late Roman wall circuit. The nearly central, cross-vaulted nymphaeum (bays XI-XII) was reused in the Middle Byzantine period for religious purposes, when a church was built nearby; possibly this was the church and monastery founded by $\mathrm{St}$ Nikon Metanoeites $c .975$. Occupation continued until c.1350. Interpretation of the topography of Sparta in the light of the new evidence from the stoa suggests that the still elusive agora may have been on the upper plateau $\mathrm{N}$ of the stoa, rather than beneath the stadium to the $s$.

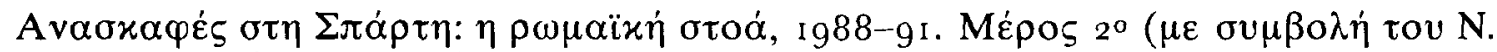
FRADGLEY) (Пivaxes 53-72)

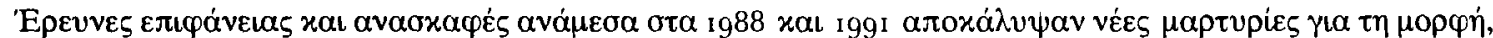

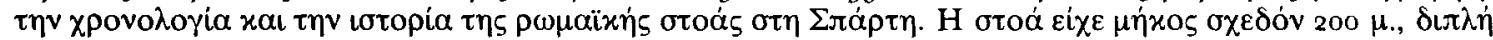

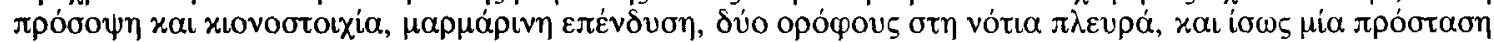




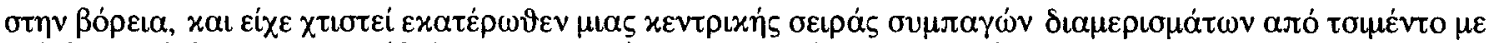

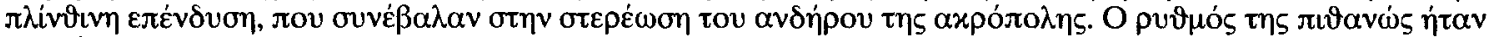

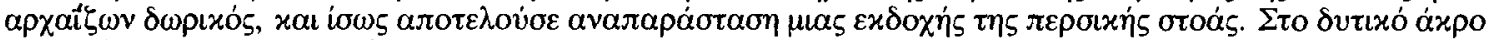

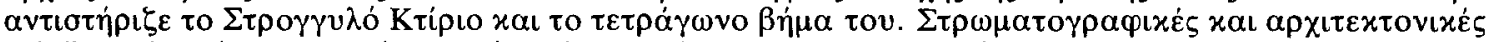

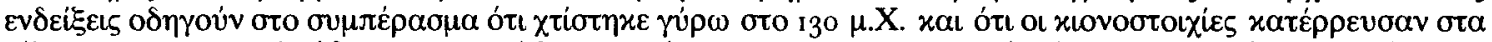

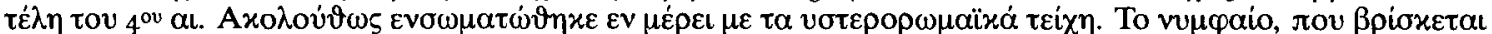

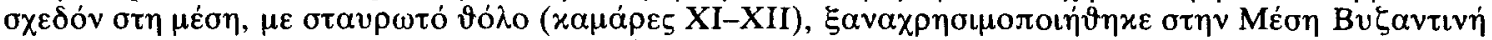

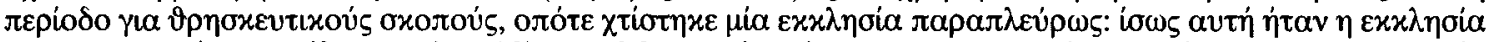

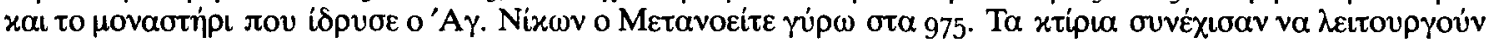

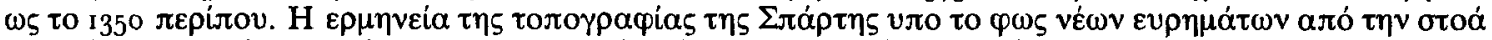

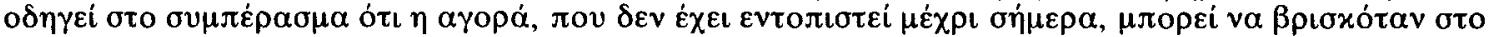

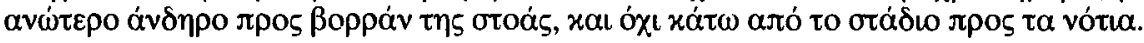

JUDITH WEINGARTEN

$151-6$

Seal-use and administration in the South-west Basement Area at Knossos (Plate 20)

New soundings in the area of the Room of the Clay Signet provide a terminus post quem of LM II for the sealings and clay signet fallen into the SW Basement Area of the palace of Knossos. Based on this chronological datum, the sphragistic documents are reviewed together with the Linear B tablets with which they fell, in an attempt to reconstruct the administrative activity carried out in the rooms above the SW Basement. We pinpoint an unexpected bureaucratic connection between this area of the palace and the arsenal.

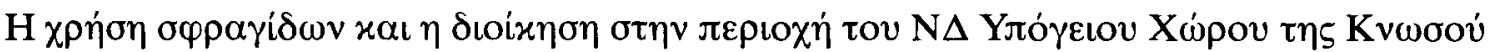 (Пivaxas 20)}

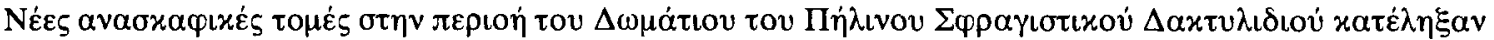

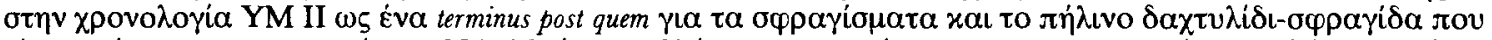

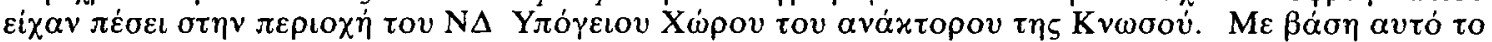

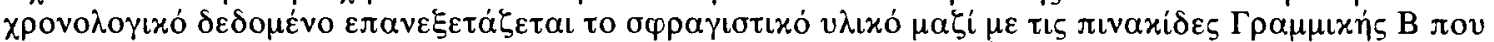

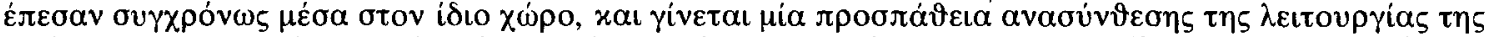

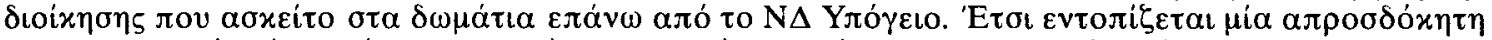

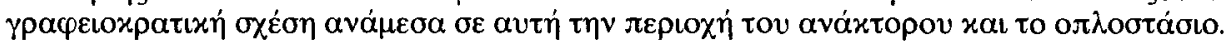

Ceramic regionalism in Prepalatial central Crete: the Mesara imports at EM I to EM II A Knossos (Plates I-13)

This article presents results obtained through detailed stylistic analysis of a body of EM I-EM II A pottery at Knossos in association with a programme of petrographic analysis and scanning electron microscopy. From the Knossian ceramic assemblage, four specific ware groups were chosen for this study on the basis of shape, decoration, and fabric: fine painted, fine grey, painted semi-fine to coarse, and slipped and burnished. It is argued here, on stylistic grounds and on the basis of petrographic analysis, that these groups were imported to Knossos from south central Crete. In addition, scanning electron microscopy characterizes the technology of production of the Mesara imports, and demonstrates the use of oxidation-reduction-oxidation techniques to produce black in this early period. The Mesara imports at EM II A Knossos mark the first sizeable exchange of pottery at this site in Minoan times. They suggest that in central Crete by EM II A there may have been an inter-regional distribution of a broad range of pottery types from various specialized production centres. 


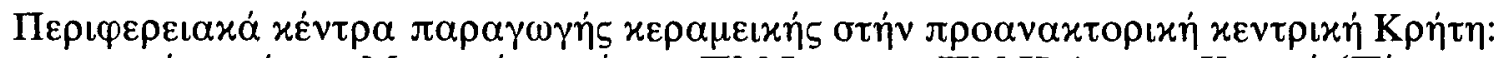

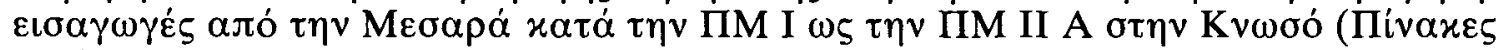
$\mathrm{I}-\mathrm{I} 3)$

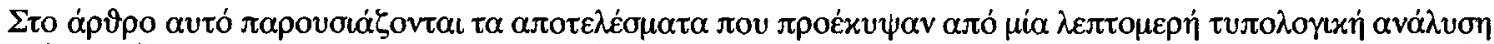

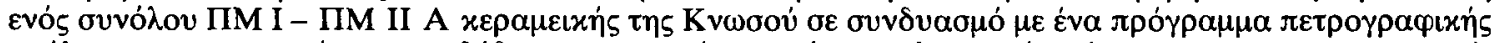

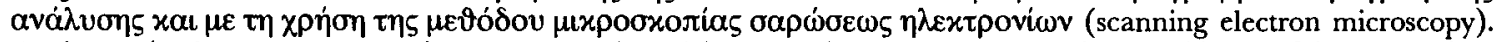

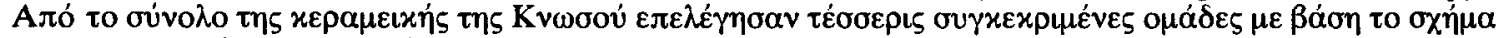

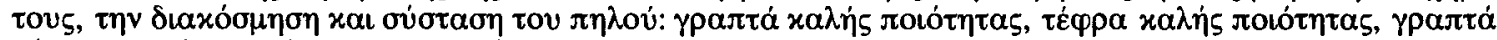

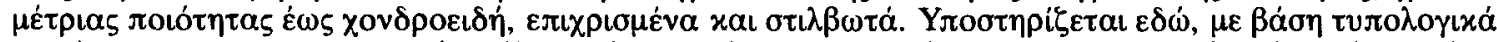

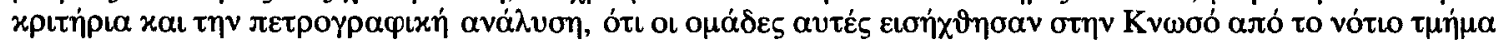

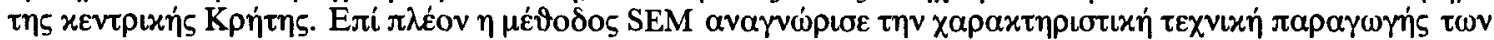

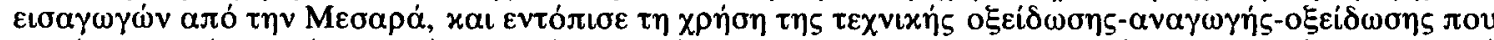

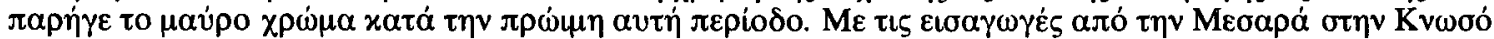

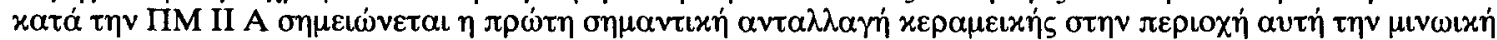

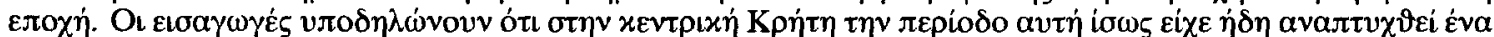

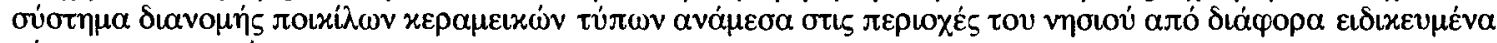

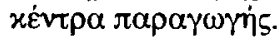

